\title{
ANALISIS SEBARAN LOKASI STASIUN PENGISIAN BAHAN BAKAR UMUM (SPBU) DI KABUPATEN GORONTALO Distribution Analysis of The Location of Public Fuel Filling Stations (SPBU) in Gorontalo District
}

\author{
Almijan Yusuf ${ }^{1}$, Arthur Gani Koto ${ }^{2}$ \\ ${ }^{1,2}$ Program Studi Geografi, Universitas Muhammadiyah Gorontalo, Indonesia \\ Email Korespondensi: arthur@umgo.ac.id
}

DOI: $10.31314 /$ jsig.v3i2.662

Abstract - Gorontalo District, which is geographically located in the middle of Gorontalo Province and is traversed by the Trans Sulawesi road, is the main transportation route from Central Sulawesi, Pohuwato Regency and Boalemo Regency to the east, as well as from North Sulawesi Province, Gorontalo City and Bone Bolango Regency to the west. The mobility of the vehicle that passes every time requires the consumption of fuel oil (BBM). The supply of BBM by Pertamina through the Public Fuel Filling Station (SPBU) is one of the main infrastructure available. The purpose of this study is to examine the spatial distribution of gas stations in Gorontalo District. The navigation measurement tool in the form of GPS is used to take the coordinates of gas stations based on field checks. Nearest neighbor analysis method is used to calculate the distribution pattern of location points between gas stations. The results showed that the distribution of SPBU location points in Gorontalo District formed a uniform (linear) pattern and the location distance between SPBUs was included in the very far criteria.

Keywords: spbu, spatial, gorontalo regency, nearest neighbour

\begin{abstract}
Abstrak - Kabupaten Gorontalo yang letak geografisnya berada di tengah Provinsi Gorontalo dan dilalui jalan Trans Sulawesi merupakan jalur transportasi utama dari wilayah Sulawesi Tengah, Kabupaten Pohuwato dan Kabupaten Boalemo ke arah timur, serta dari Provinsi Sulawesi Utara, Kota Gorontalo dan Kabupaten Bone Bolango ke arah barat. Mobilitas kendaraan yang tiap saat melintas tentunya memerlukan konsumni bahan bakar minyak (BBM). Suplai BBM oleh Pertamina melalui Stasiun Pengisian Bahan Bakar Umum (SPBU) merupakan salah satu prasarana pokok yang tersedia. Tujuan penelitian ini adalah untuk mengkaji sebaran lokasi SPBU di Kabupaten Gorontalo secara spasial. Alat ukur navigasi berupa GPS digunakan untuk pengambilan titik koordinat SPBU berdasarkan cek lapangan. Metoda analisis tetangga terdekat (nearest neighbour analysis) digunakan untuk menghitung pola sebaran titik lokasi antar SPBU. Hasil penelitian menunjukkan bahwa sebaran titik lokasi SPBU di Kabupaten Gorontalo membentuk pola seragam (linear) dan jarak lokasi antar SPBU termasuk dalam kriteria sangat jauh.
\end{abstract}

Kata kunci: spbu, spasial, kabupaten gorontalo, nearest neighbour 


\section{PENDAHULUAN}

Jalan Trans Sulawesi yang membelah Kabupaten Gorontalo merupakan jalan utama arus kendaraan dari arah barat (Provinsi Sulteng, Kab. Pohuwato, dan Kab. Boalemo) menuju Kota Gorontalo, Kabupaten Boalemo dan Provinsi Sulawesi Utara (Sulut). Kabupaten Gorontalo merupakan wilayah yang mengalami perkembangan dalam bidang industri, pariwisata dan pertanian. Kegiatan di bidang industri, pertanian dan pariwisata tersebut menimbulkan suatu peningkatan mobilitas. Peningkatan mobilitas di berbagai bidang tersebut berimbas pada meningkatnya kebutuhan akan BBM. Arus kendaraaan yang hilir mudik di jalan Trans Sulawesi sering dilalui oleh kendaraan dengan kode wilayah luar Provinsi Gorontalo. Tentu saja kendaraankendaraan tersebut memerlukan konsumsi BBM selama dalam perjalanan.

Satu-satunya perusahaan penyalur dan penjualan BBM di Kabupaten Gorontalo yang menjual produknya di SPBU yaitu Pertamina. Seluruh SPBU yang ada di Kabupaten Gorontalo menjual BBM dalam 4 jenis, yaitu premium (RON 88), pertalite (RON 90), pertamax (RON 92) dan solar. Data (RTRW Provinsi Gorontalo, 2010) menunjukkan bahwa wilayah Kabupaten Gorontalo berada pada kawasan strategis sebab dapat memberikan keuntungan ekonomi yang tinggi, termasuk salah satunya adalah dalam hal penjualan BBM di SPBU. Jumlah penduduk yang mencapai 374.923 jiwa (Kabupaten Gorontalo Dalam Angka, 2018) merupakan terbesar di Provinsi Gorontalo sehingga membutuhkan SPBU yang banyak pula.

Pendirian lokasi SPBU harus memperhatikan penggunaan lahan dan kawasan yang telah ditetapkan oleh RTRW pemerintah daerah. Pendirian SPBU tersebut membutuhkan syarat yaitu apakah lokasi tersebut berada di wilayah perumahan, pertokoan, perkantoran, atau kawasan industri. Setiap lokasi pendirian SPBU dalam kawasan penggunaan lahan yang telah ditetapkan dapat mempengaruhi persetujuan untuk diberikan izin mendirikan SPBU atau tidak.

SPBU adalah lokasi penerimaan, penyimpanan dan penyaluran BBM yang melayani konsumen secara eceran/ritel dan dikhususkan untuk kendaraan bermotor, atau depot BBM dengan kapasitas tangki timbun BBM yang terbatas. Ada empat distributor BBM di Indonesia yang menjual produknya di SPBU, yaitu Pertamina-Indonesia, Shell-Belanda, Petronas-Malaysia, dan Total-Perancis (Risdiyanta, 2014). PT. Pertamina merupakan salah satu perusahaan Badan Usaha Milik Negara (BUMN) yang bergerak dibidang bisnis minyak, dan non -BBM, gas, petrokimia, dan pelumas baik di Indonesia maupun di negara lain (Theis, 2013). Kilang dalam negeri yang dimiliki oleh PT PERTAMINA yaitu : a) Refinery Unit II Dumai, b) Refinery Unit III Plaju dan Sungai Gerong, c) Refinery Unit IV Cilacap, d) Refinery Unit V Balikpapan, e) Refinery Unit VI Balongan, dan f) Refinery VII Kasim Sorong.

Untuk menentukan tipe-tipe SPBU telah dikelompokan berdasarkan sarana dan prasarana yang dimiliki, meliputi volume penjualan (thoughput, luas lahan, dan jumlah dispenser) hal ini nanti berkaitan jumlah fee yang harus dibayarkan ke Pertamina.

Tabel 1. Tipe SPBU pertamina dan besarnya initial fee

\begin{tabular}{ccc}
\hline Tipe SPBU & $\begin{array}{c}\text { Perkiraan Volume Penjualan (kilo } \\
\text { liter) }\end{array}$ & Besarya Initial Fee (dalam juta rupiah) \\
\hline A & $>35$ & 800 \\
B & $>25 \mathrm{~s} / \mathrm{d} \geq 35$ & 650 \\
C & $>20 \mathrm{~s} / \mathrm{d} \geq 25$ & 500 \\
D & $>15 \mathrm{~s} / \mathrm{d} \geq 20$ & 350 \\
E & $\geq 15$ & 250 \\
\hline
\end{tabular}

(Sumber : www. spbu.pertamina.com, 2018)

Lahan untuk SPBU adalah suatu lokasi dengan luas tertentu yang digunakan untuk kegiatan operasional pemasaran BBM dan Non BBM. Kegiatan ini meliputi penerimaan, pembongkaran, penimbunan dan penyaluran/ penyerahan maupun pengisian. Dasar perhitungan luas lahan berdasarkan pada perkiraan jumlah kebutuhan BBM dan Non BBM minimum untuk jangka waktu 5 (lima) tahun mendatang, sehingga kapasitas tangki yang dibutuhkan dapat dirancang sesuai kebutuhan. Tipe SPBU berdasarkan dari luas lahan yang dimiliki untuk unit bisnis yang dijalankan, luas lahan terkait dengan lebar muka jalan, kapasitas tangki, panjang selang dispenser dan lainnya. 
Yusuf, A \& Koto, A. G., 2020 Jurnal Sains Informasi Geografi [J SIG], 3(2):108-116, ISSN 2614-1671

Tabel 2. Luasan dan tipe tangki BBM pada SPBU Pertamina

\begin{tabular}{lccccc}
\hline \multicolumn{1}{c}{ Komponen } & Tipe A & Tipe B & Tipe C & Tipe D & Tipe E \\
\hline Minimal Ukuran Lahan $\left(\mathrm{m}^{2}\right)$ & 2.500 & 1.600 & 1.225 & 900 & 700 \\
Minimal lebar muka jalan $(\mathrm{m})$ & 50 & 40 & 35 & 30 & 20 \\
Selang (buah) & Min 26 & $20-25$ & $16-20$ & $10-16$ & Max 10 \\
Kapasitas tangki (kl) & Min 160 & Min 140 & Min 100 & Min 80 & Min 60 \\
\hline
\end{tabular}

(Sumber : www. spbu.pertamina.com, 2018)

Operasional SPBU Pertamina digolongkan ada tiga jenis SPBU COCO (Corporate Owned Corporated Operated), yaitu SPBU yang sepenuhnya dimiliki oeh PT Pertamina (Persero) dalam hal ini Pertamina Ritel, SPBU CODO (Corporate Owned Dealer Operated), yaitu SPBU yang operasionalnya merupakan kerjasama antara Pertamina dengan swasta dalam hal kepemilikan lahan ataupun lainnya, SPBU DODO (Dealer Owned Dealer Operated), yaitu SPBU yang sepenuhnya dimiliki swasta tapi membeli lisensi merk Pertamina.

Timbulnya persaingan antar SPBU salah satunya diakibatkan oleh perhitungan jarak. Jarak antara SPBU diklasifikasi seperti disajikan pada Tabel 3. SPBU yang tidak hanya berfungsi sebagai tempat pengisian BBM untuk kendaraan, memiliki fungsi lain yang dapat digunakan oleh pengendara seperti mushalla, toilet dan minimarket. Keberadaan SPBU di suatu lokasi juga menandakan adanya korelasi antara jumlah penduduk dan kendaraan bermotor (Syamsuddin, 2013). Di Kota Makassar, sebaran lokasi SPBU membentuk pola acak pada kawasan pusat kota, mengelompok pada kawasan tengah kota, dan pola mengelompok pada kawasan pinggiran kota (Zarkawi et al., 2016).

Tabel 3. Klasifikasi jarak antar SPBU

\begin{tabular}{ccc}
\hline No. & Kelas jarak $(\mathrm{km})$ & Kriteria \\
\hline 1 & $\geq 3$ & Sangat jauh \\
2 & $2,75-<3$ & Jauh \\
3 & $2,5-<2,75$ & Dekat \\
4 & $2,25-<2,5$ & Cukup dekat \\
5 & $<2,25$ & Sangat dekat \\
\hline
\end{tabular}

(Sumber : PT. Pertamina; (Sarasadi, 2011)

Pemetaan lokasi pencarian rute terpendek SPBU menggunakan Sistem Informasi Geografis (SIG) berbasis web di Kota Padang, dapat memberikan informasi dan membantu pengguna dalam melakukan pencarian lokasi SPBU berdasarkan nama dan rute terpendek antar lokasi SPBU. Lokasi SPBU tersebut ditampilkan dalam bentuk peta jalan Kota Padang (Junanda et al., 2016).

Beberapa SPBU di Kabupaten Gorontalo cenderung mengelompok di wilayah yang ramai arus kendaraan dan kawasan pemukiman. Sebaliknya, SPBU yang merupakan jalur kendaraan dari arah barat menuju Provinsi Sulut hanya berjumlah dua buah dan letaknya sangat berjauhan. Bagi sebagian masyarakat Kabupaten Gorontalo, informasi dan ketersediaan SPBU dianggap tidak terlalu penting. Namun sebaliknya, keberadaan dan ketersediaan SPBU merupakan hal penting bagi pengendara dari luar provinsi yang baru pertama kali ke Gorontalo dan tidak mengetahui letak SPBU. Memanfaatkan jaringan internet, lokasi SPBU sebetulnya dengan mudah dapat diketahui sehingga hal tersebut bukan masalah bagi pengendara dari luar Provinsi Gorontalo.

Atas dasar tersebut diatas, maka timbul suatu permasalahan yaitu bagaimana sebaran lokasi SPBU di Kabupaten Gorontalo secara spasial?. Penelitian ini bertujuan untuk mengkaji sebaran lokasi SPBU di Kabupaten Gorontalo secara spasial.

\section{METODE DAN DATA}

Obyek penelitian ini adalah SPBU yang terdapat di Kabupaten Gorontalo. Kabupaten Gorontalo merupakan salah satu Kabupaten di Provinsi Gorontalo yang secara administratif berbatasan dengan Kabupaten Gorontalo Utara di sebelah utara, Teluk Tomini di sebelah selatan, Kota Gorontalo di sebelah timur, dan Kabupaten Boalemo di sebelah barat. Kabupaten Gorontalo mempunyai luas wilayah $2.125,47 \mathrm{~km}^{2}$ yang terdiri atas 19 Kecamatan (Kabupaten Gorontalo 
Dalam Angka, 2018).

Alat yang digunakan dalam penelitian ini yaitu alat ukur navigasi berupa GPS Garmin Oregon 650 yang berfungsi untuk pengambilan titik koordinat SPBU. Data yang digunakan yaitu Peta Digital Administrasi Kabupaten dan Provinsi Gorontalo (Peta Digital BPS, 2017), jaringan jalan dari website openstreet map (openstreetmap.org, 2017), data jumlah kendaraan bermotor dari SAMSAT Kabupaten Gorontalo Tahun 2017, dan observasi lapangan.

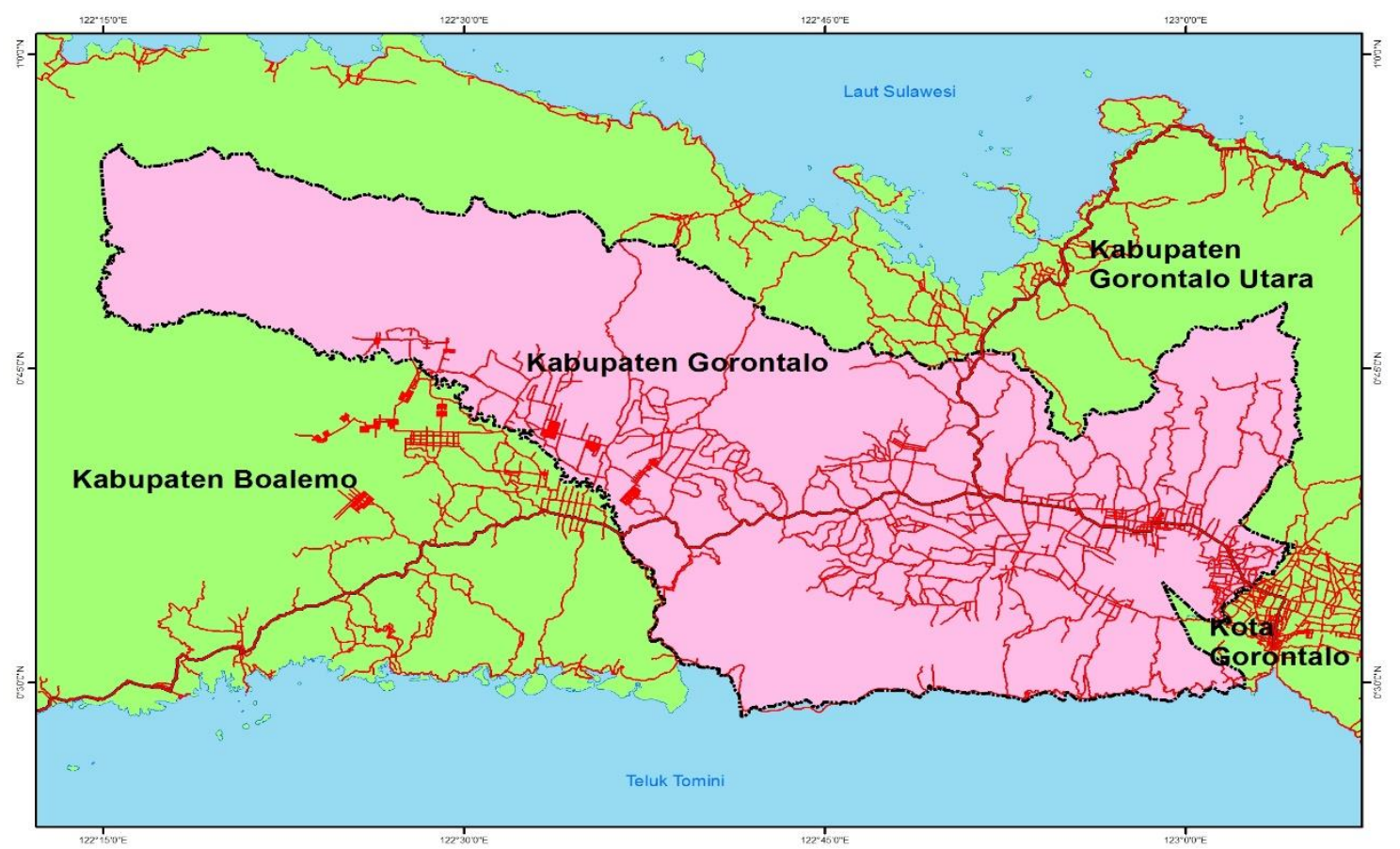

Gambar 1. Peta Lokasi Penelitian

Pengumpulan data tiap SPBU diambil titik koordinat, letak administrasi, dokumentasi, dan pengamatan jumlah selang. Wawancara dilakukan kepada pengelola SPBU untuk pengumpulan data omset penjualan rata-rata BBM/hari. Penentuan ketersediaan SPBU menggunakan metode analisis tetangga terdekat (nearest neighbour). Metode nearest neighbour dijabarkan dalam persamaan (1) di bawah :

$T=\frac{J u}{J h} \ldots$

Dimana, $\mathrm{T}=$ indeks persebaran tetangga terdekat

$\mathrm{Ju}=$ jarak rata-rata yang diukur antara satu titik dengan titik tetangga terdekat

$\mathrm{Jh}=$ jarak yang diperoleh andai semua titik mempunyai pola acak

Persamaan yang digunakan untuk mencari nilai Jh yaitu :

$J h=\frac{1}{2 \sqrt{ } p}$.

Dimana, $\mathrm{p}=$ kepadatan penduduk atau kepadatan titik $\left(\mathrm{km}^{2}\right)$ untuk mencari nilai $\mathrm{p}$, digunakan persamaan (3):

$p=\frac{N}{A}$

Dimana, $\mathrm{N}=$ jumlah titik

$\mathrm{A}=$ luas wilayah $\left(\mathrm{km}^{2}\right)$

Nilai $\mathrm{T}$ pada persamaan di atas yaitu $0-2,15$. Jika nilai $\mathrm{T}=0$, maka pola sebarannya 
mengelompok (cluster), jika $\mathrm{T}=1$ pola sebarannya acak (random), dan jika $\mathrm{T}=2,15$ pola sebarannya seragam (regular). Nilai $\mathrm{T}$ selanjutnya dijabarkan dengan continum nearest neighbour analysis berikut:

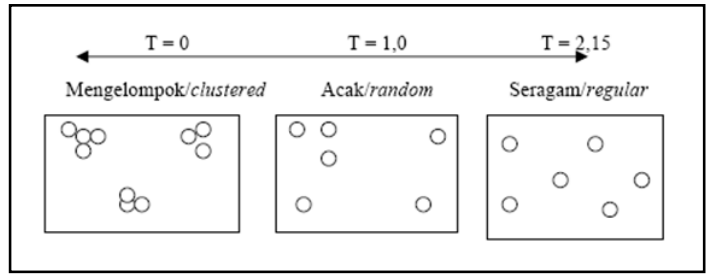

Sumber : Bintarto \& Surastopo, 1979

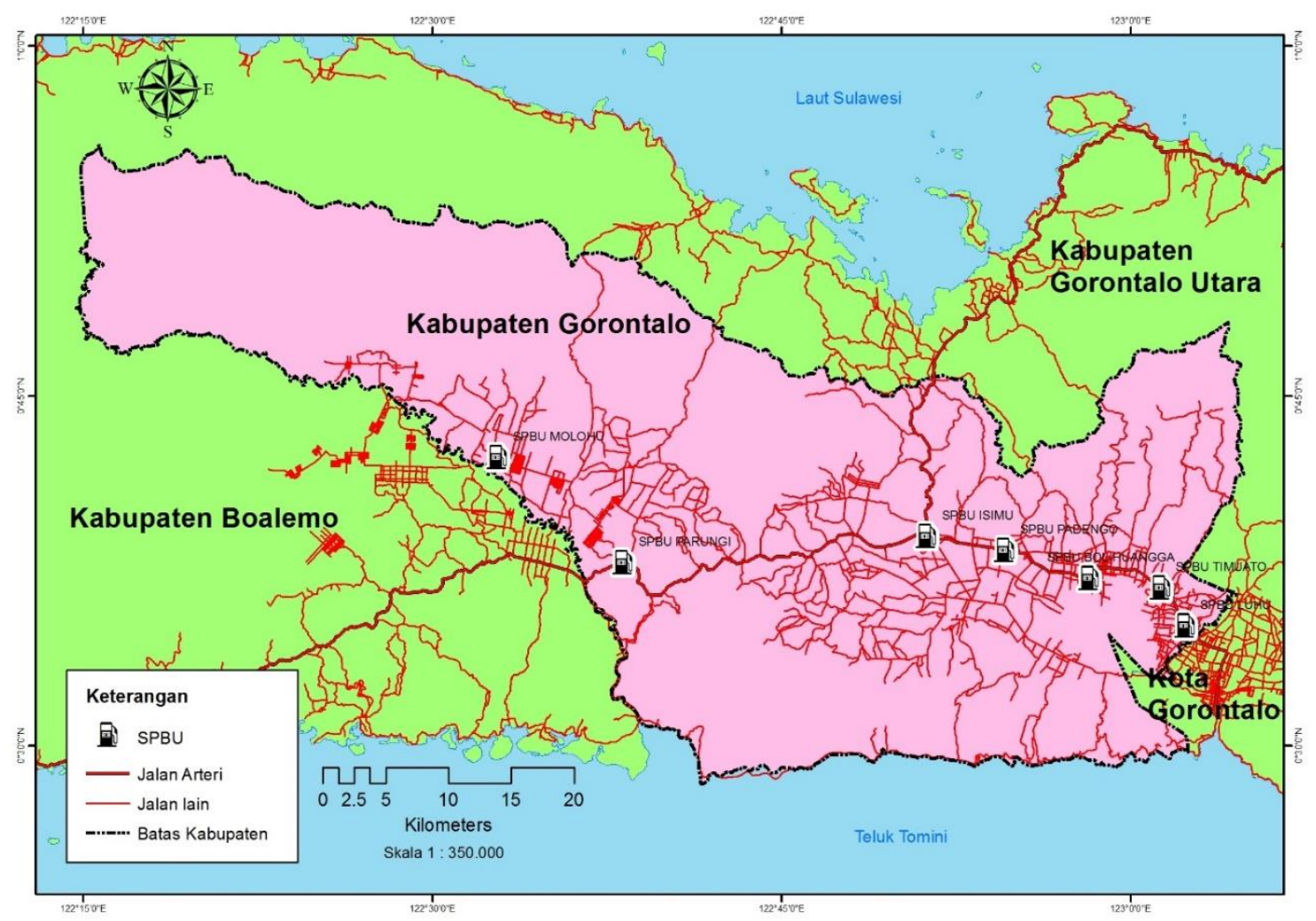

Gambar 2. Peta Lokasi Sebaran SPBU Kabupaten Gorontalo (Sumber: Cek lapangan, 2017)

\section{HASIL DAN PEMBAHASAN}

Tahun 2001 yang merupakan awal terbentuknya Provinsi Gorontalo, jumlah kendaraan sebanyak 26.181 ribu kendaraan (Dinas Pendapatan Daerah Provinsi Gorontalo, personal communication, 2002). Pada tahun 2016, jumlah kendaraan di Kabupaten Gorontalo sebanyak 69.251 buah kendaraan (SAMSAT Kabupaten Gorontalo, personal communication, 2016). Hal tersebut menandakan bahwa jumlah kendaraan semakin meningkat, dimana untuk lebih besar pada level kabupaten.

Data SAMSAT Kabupaten Gorontalo Tahun 2017, menunjukkan jumlah kendaraan bermotor sebanyak 69.251 buah. Berdasarkan survei lapangan, terdapat tujuh SPBU yang tersebar di tujuh kecamatan, enam diantaranya terletak di Jalan Trans Sulawesi dan satu di jalan penghubung antar kecamatan. Salah satu alasan keberadaan SPBU di Desa Molohu Kecamatan Tolangohula adalah karena adanya perkebunan tebu dan pabrik gula serta kawasan persawahan. Di lokasi tersebut kendaraan jenis truk hilir mudik mengangkut hasil bumi (tebu, kelapa, padi, sawit). 


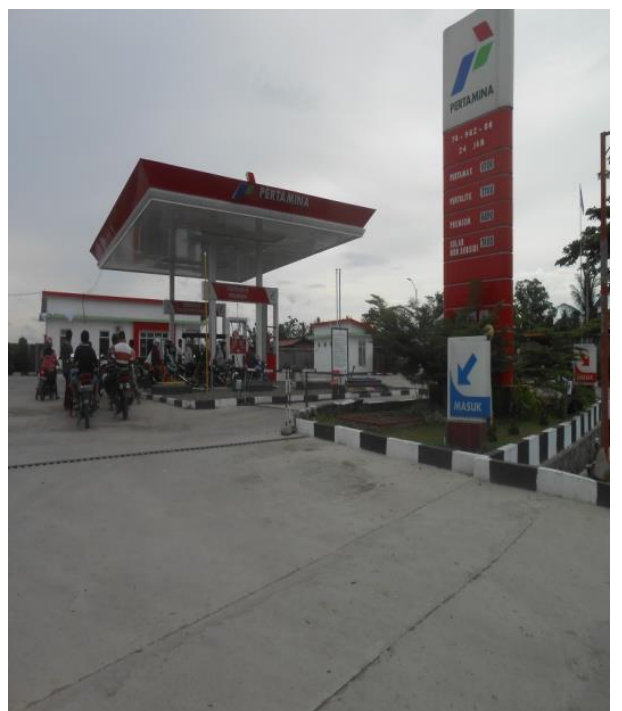

Gambar 3. SPBU 74.962.08 Desa Molohu Kec. Tolangohula

Sebaran lokasi SPBU di Kabupaten Gorontalo disajikan pada Gambar 2. Letak SPBU secara administratif, selengkapnya disajikan pada Tabel 4.

Tabel 4. Koordinat lokasi SPBU di Kabupaten Gorontalo

\begin{tabular}{cccl}
\hline \multirow{2}{*}{ No. SPBU } & \multicolumn{2}{c}{ Koordinat } & \multicolumn{1}{c}{ Alamat } \\
\cline { 2 - 3 } & Latitude & Longitude & \\
\hline 74.961 .06 & $00^{\circ} 35^{\prime} 10.4^{\prime \prime}$ & $123^{\circ} 02^{\prime} 19.2^{\prime \prime}$ & Desa Luhu Kec. Telaga \\
74.961 .02 & $00^{\circ} 36^{\prime} 48.3^{\prime \prime}$ & $123^{\circ} 01^{\prime} 15.0^{\prime \prime}$ & Desa Timuato Kec. Telaga Biru \\
74.962 .28 & $00^{\circ} 37^{\prime} 12.3^{\prime \prime}$ & $122^{\circ} 58^{\prime} 11.7^{\prime \prime}$ & Kel. Bolihuangga Kec. Limboto \\
74.961 .08 & $00^{\circ} 38^{\prime} 24.1^{\prime \prime}$ & $122^{\circ} 54^{\prime} 34.6^{\prime \prime}$ & Desa Padengo Kec. Limboto Barat \\
74.962 .26 & $00^{\circ} 39^{\prime} 00.6^{\prime \prime}$ & $122^{\circ} 51^{\prime} 13.2^{\prime \prime}$ & Desa Isimu Selatan Kec. Tibawa \\
74.962 .31 & $00^{\circ} 37^{\prime} 52.2^{\prime \prime}$ & $122^{\circ} 38^{\prime} 11.4^{\prime \prime}$ & Desa Parungi Kec. Boliyohuto \\
74.962 .08 & $00^{\circ} 42^{\prime} 23.4^{\prime \prime}$ & $122^{\circ} 32^{\prime} 47.6^{\prime \prime}$ & Desa Molohu Kec. Tolangohula \\
\hline
\end{tabular}

(Sumber : Survei Lapangan, 2017)

Penjualan rata-rata BBM/hari tiap SPBU disajikan pada Tabel 5.

Tabel 5. Penjualan rata-rata tiap SPBU BBM/hari di Kabupaten Gorontalo

\begin{tabular}{cccccc}
\hline \multirow{2}{*}{ SPBU } & Kecamatan & \multicolumn{3}{c}{ Penjualan rata-rata/hari (liter) } \\
\cline { 3 - 5 } & & Premium & Pertalite & Pertamax & Solar \\
\hline 74.961 .06 & Telaga & 8.000 & 7.000 & 1.000 & 8.000 \\
74.961 .02 & Telaga Biru & 9.000 & 1.000 & 7.000 & 8.000 \\
74.962 .28 & Limboto & 8.000 & 7.000 & 400 & 5.000 \\
74.961 .08 & Limboto Barat & 8.000 & 5.000 & 900 & 6.000 \\
74.962 .26 & Tibawa & 8.000 & 8.000 & 800 & 7.000 \\
74.962 .31 & Boliyohuto & 8.000 & 5.000 & 250 & 7.000 \\
74.962 .08 & Tolangohula & 8.000 & 3.000 & 200 & 6.000 \\
\hline
\end{tabular}

(Sumber: Pengolahan data primer, 2017)

Berdasarkan Tabel 5 diketahui bahwa penjualan BBM/hari tiap SPBU untuk jenis premium hampir sama jumlahnya. BBM jenis pertamax yang merupakan non-subsidi mencapai penjualan paling sedikit diantara BBM jenis lainnya. Tercatat penjualan pertamax paling sedikit terjadi di Desa Molohu Kecamatan Tolangohula (200 liter/hari) dan paling banyak di Kecamatan Telaga Biru dan Telaga (8.000 liter/hari). Jumlah selang yang terdapat pada tiap SPBU tidak sama. Tercatat hanya satu SPBU yang memiliki jumlah selang 12 buah dan yang lainnya kurang dari 12 buah. PT. Pertamina telah membagi tipe tiap SPBU berdasarkan jumlah selang yang dimiliki, 
Yusuf, A \& Koto, A. G., 2020 Jurnal Sains Informasi Geografi [J SIG], 3(2):108-116, ISSN 2614-1671

seperti pada Tabel 2 diatas. Tipe SPBU berdasarkan jumlah selang selengkapnya disajikan pada Tabel 6.

Tabel 6. Jumlah selang tiap SPBU di Kabupaten Gorontalo

\begin{tabular}{|c|c|c|c|c|c|c|c|}
\hline \multirow[b]{2}{*}{ SPBU } & \multirow[b]{2}{*}{ Lokasi } & \multicolumn{4}{|c|}{ Penjualan rata-rata/hari (liter) } & \multirow{2}{*}{$\begin{array}{l}\text { Jumlah } \\
\text { (buah) }\end{array}$} & \multirow[b]{2}{*}{ Tipe } \\
\hline & & $\begin{array}{l}\text { Pertamax } \\
92\end{array}$ & Premium & Pertalite & Solar & & \\
\hline 74.961 .06 & $\begin{array}{l}\text { Desa Luhu Kec. } \\
\text { Telaga }\end{array}$ & 4 & 2 & 4 & 2 & 12 & $\mathrm{D}$ \\
\hline 74.961 .02 & $\begin{array}{l}\text { Desa Timuato, } \\
\text { Kec. Telaga Biru }\end{array}$ & 2 & 2 & 4 & 2 & 10 & $\mathrm{D}$ \\
\hline 74.962 .28 & $\begin{array}{l}\text { Kel. } \\
\text { Bolihuangga, } \\
\text { Kec. Limboto }\end{array}$ & 1 & 3 & 2 & 2 & 8 & E \\
\hline 74.961 .08 & $\begin{array}{l}\text { Kel. Padengo, } \\
\text { Kec. Limboto } \\
\text { Barat }\end{array}$ & 1 & 1 & 2 & 2 & 6 & $\mathrm{E}$ \\
\hline 74.962 .26 & $\begin{array}{l}\text { Desa Tibawa, } \\
\text { Kec. Tibawa }\end{array}$ & 2 & 3 & 2 & 2 & 10 & $\mathrm{D}$ \\
\hline 74.962 .31 & $\begin{array}{l}\text { Desa Parungi, } \\
\text { Kec. Boliyohuto }\end{array}$ & 1 & 1 & 2 & 2 & 6 & $\mathrm{E}$ \\
\hline 74.962 .08 & $\begin{array}{l}\text { Desa Molohu, } \\
\text { Kec. Tolangohula }\end{array}$ & 2 & 2 & 2 & 2 & 8 & $\mathrm{E}$ \\
\hline
\end{tabular}

(Sumber : Pengolahan data primer, 2018)

Berdasarkan Tabel 6, jumlah selang terbanyak terdapat di Kecamatan Telaga dengan 12 buah selang Pertamax 92, premium 2 buah selang, pertalite 4 buah selang, dan solar 2 buah selang. Hal tersebut ternyata tidak berhubungan dengan jumlah penduduk dalam pendirian SPBU sebab jumlah penduduk terbanyak terdapat di Kecamatan Limboto dengan jumlah 48.207 jiwa. Sedangkan di Kecamatan Limboto yang merupakan Ibukota kabupaten Gorontalo hanya ada satu SPBU.

\section{Analisis Tetangga Terdekat}

Pola sebaran SPBU berdasarkan analisis tetangga terdekat dengan obyek titik koordinat SPBU yang diambil menggunakan GPS.

$$
\overline{\jmath_{u}}=\frac{\sum j}{\sum n}
$$

$\mathrm{N}=$ jumlah $\mathrm{SPBU}=7$ unit

$\sum \mathrm{j}=$ jarak rata-rata diukur antara satu SPBU dengan SPBU terdekat $=149,6 \mathrm{~km}$

$\mathrm{A}=$ luas wilayah Kabupaten Gorontalo $=2.125,47 \mathrm{~km}^{2}$

$$
\begin{aligned}
\bar{J}=\frac{\sum j}{\sum n} & =149,6 / 7 \\
& =21,37 \mathrm{~km}
\end{aligned}
$$

Kemudian dihitung nilai $\mathrm{p}=7 / 2 \cdot 125,47=0,003 \mathrm{~km}^{2}$.

$$
\begin{aligned}
\overline{J_{h}} & =\frac{1}{2 \sqrt{0,003}} \\
& =9,1287 \mathrm{~km}^{2}
\end{aligned}
$$

Nilai nearest neighbour analysis diperoleh dengan menghitung :

$$
\mathrm{T}=\frac{21,37}{9,1287}=2,34
$$


Yusuf, A \& Koto, A. G., 2020 Jurnal Sains Informasi Geografi [J SIG], 3(2):108-116, ISSN 2614-1671

Perolehan angka $\mathrm{T}=2,34$ yang mendekati nilai 2,15 yang berarti indeks persebaran tetangga terdekatnya adalah membentuk pola seragam (regular).

\section{Klasifikasi jarak SPBU}

Jarak antara satu SPBU dengan SPBU lainnya dihitung dengan menggunakan GPS. Sebaran SPBU di Kabupaten Gorontalo membentuk pola memanjang (timur-barat). Perhitungan jarak di mulai wilayah timur dari SPBU 74.961.06 Desa Luhu hingga ke SPBU 74.962.08 Desa Molohu. Hasil perhitungan jarak antar SPBU tersebut sebagaimana disajikan pada Gambar 4.

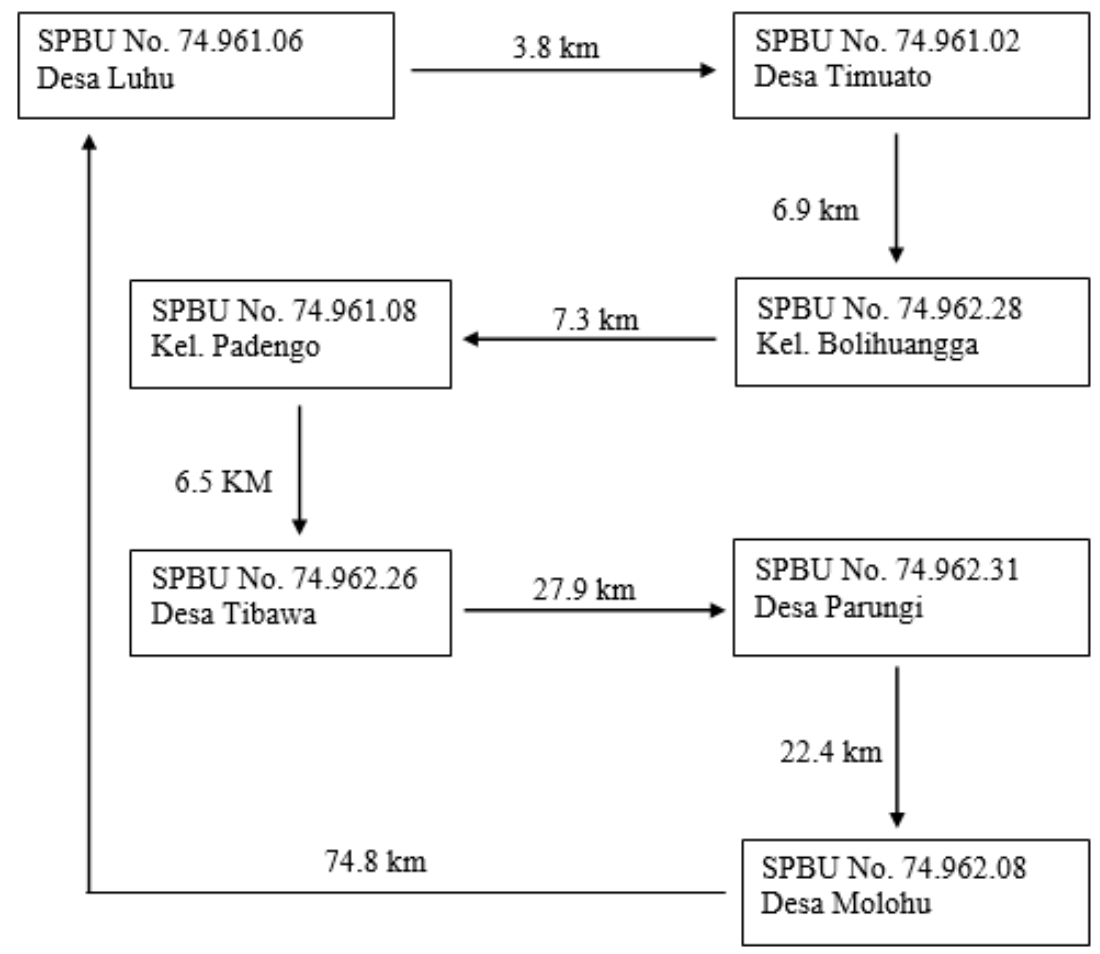

Gambar 4. Perhitungan jarak antar SPBU

Berdasarkan Tabel 3, maka dihitung jarak/batasan area antar SPBU dengan teknik buffer pada perangkat lunak pengolah data spasial. Masing-masing batasan area tersebut dilakukan pada jarak $3 \mathrm{~km}, 2.75 \mathrm{~km}, 2.5 \mathrm{~km}$, dan $2.25 \mathrm{~km}$. Peta wilayah buffer pada masing-masing jarak SPBU diatas disajikan pada Gambar 5. Pada Gambar 5 terlihat bahwa jarak antara SPBU Luhu dengan SPBU Timuato yang berada dalam radius $2,25 \mathrm{~km}$ termasuk kriteria sangat dekat. SPBU Bolihuangga dan SPBU Timuato masuk dalam kriteria dekat yang berada dalam radius $3 \mathrm{~km}$, sedangkan SPBU lainnya masuk dalam kriteria sangat jauh.

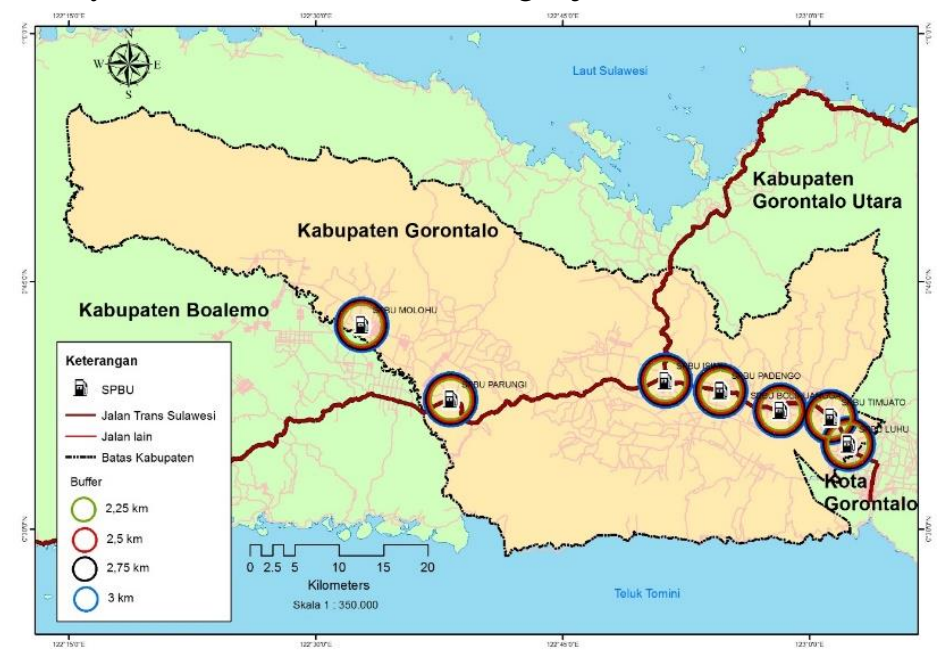

Gambar 5. Peta buffering lokasi SPBU 


\section{KESIMPULAN}

SPBU yang merupakan salah satu fasilitas penting yang harus tersedia bagi kendaraan bermotor. Penggunaan metode nearest neighbour dapat digunakan untuk analisis sebaran lokasi SPBU. Sebaran lokasi SPBU yang termasuk dalam kelompok seragam (linear), tidak sesuai dengan luas wilayah administrasi Kabupaten Gorontalo karena tersebar tidak merata. Secara umum, jarak lokasi antar SPBU termasuk kriteria sangat jauh sehingga kedepannya dalam pendirian SPBU perlu memperhatikan kondisi wilayah dan posisi.

\section{DAFTAR PUSTAKA}

Bintarto, R., \& Surastopo, H. (1979). Metode Analisa Geografi. LP3ES.

Dinas Pendapatan Daerah Provinsi Gorontalo. (2002). [Personal communication].

Junanda, B., Kurniadi, D., \& Huda, Y. (2016). Pencarian Rute Terpendek Menggunakan Algoritma Dijkstra Pada Sistem Informasi Geografis Pemetaan Stasiun Pengisian Bahan Bakar Umum. Jurnal Voteknika, 4(1), 107-115.

Kabupaten Gorontalo Dalam Angka. (2018). BPS Kabupaten Gorontalo.

Openstreetmap. (2017). https://www.openstreetmap.org/\#map=12/0.6509/122.9260

Peta Digital BPS. (2017). [Map]. Badan Pusat Statistik (BPS).

RTRW Provinsi Gorontalo. (2010). Dinas Pekerjaan Umum Provinsi Gorontalo.

SAMSAT Kabupaten Gorontalo. (2016). SAMSAT Kabupaten Gorontalo [Personal communication].

Sarasadi, A. (2011). Evaluasi Sebaran Spasial Lokasi Stasiun Pelayanan Bahan Bakar Umum (SPBU) Pertamina Di Kota Semarang Berbasis Sistem Informasi Geografis [Skripsi]. Universitas Negeri Semarang.

Syamsuddin, Muh. (2013). Sistem Informasi Geografis (SIG) Stasiun Pengisian Bahan Bakar Umum (SPBU) di Samarinda [Skripsi]. Politeknik Pertanian Negeri Samarinda.

Theis, R. (2013). Pengelolaan Rantai Pasokan Terhadap Pemenuhan Kebutuhan BBM Pada SPBU Di Kota Manado. Jurnal EMBA, 1(3), 821-828.

Zarkawi, A. M., Akil, A., \& Natalia, V. V. (2016). Evaluasi Pola Persebaran Stasiun Pengisian Bahan Bakar Umum (SPBU) di Kota Makassar. Prosiding Temu Ilmiah IPLBI, 7-14. 